\section{HYGIENIC PROBLEMS OF WATER SUPPLY IN TERNOPIL REGION}

Lototska O.V., Kondratiuk V.A., Panichev V.O ГІГІЕНИЧНІ ПРОБЛЕМИ ВОДОПОСТАЧАННЯ
У ТЕРНОПЛЬСЬКІЙ ОБЛАСТІ

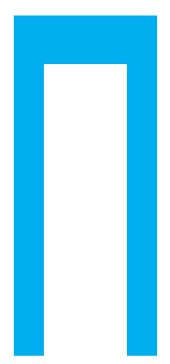

ЛОТОЦЬКА О.В., КОНДРАТЮК В.А., ПАНИЧЕВ В.О.

ДВНЗ „Тернопільський державний медичний університет

ім. І.Я. Горбачевського МОЗ України",

ДУ «Тернопільський обласний лабораторний центр

м03 України», м. Тернопіль

УДК 614.777

Ключові слова:

якість води, централізоване водопостачання, децентралізоване водопостачання. роблема якості питної води для України була і залишається вкрай актуальною і надзвичайно гострою $[1,2]$. Це пов'язано з тим, що Україна належить до держав $з$ обмеженою кількістю водних ресурсів та високим ступенем їх використання. За даними Національного інституту стратегічних досліджень, високий відсоток проб питної води із централізованих систем водопостачання не відповідає вимогам Держстандарту. До 30\% досліджених проб питної води із джерел децентралізованого водопостачання не відповідають санітарним нормам за санітарно-хімічними показниками й до 20\% - за бактеріологічними. Таке становище призводить до зростання інфекційної та неінфекційної захворюваності населення [3].

Якість питної води і санітарний стан джерел водопостачання свідчать про збільшення питомої ваги водного фактора у формуванні шкідливого впливу об'єктів довкілля на здо- ров'я людей. Негативні тенденції з забезпеченням населення питною водою у достатній кількості та високої якості на сьогодні набули критичного стану у багатьох регіонах України [4-6].

За даними ООН, Україна посідає 95 місце серед 112 країн світу за рейтингом якості питних джерел. За запасами місцевих водних ресурсів (1 тис. $\mathrm{M}^{3}$ на 1 особу) Україна вважається однією $з$ найменш забезпечених країн в Європі (Швеція, Німеччина - по 2,5 тис. $\mathrm{M}^{3}$, Великобританія -5 тис. ${ }^{3}$, Франція - 3,5 тис. м³ ська частина колишнього СРСР - 5,9 тис. ${ }^{3}$ ) У маловодні роки на території України формується лише 52,4 км³/рік стоку, тобто на одну людину припадає близько 1 тис. м $^{3}$. За визначенням Європейської економічної комісії $\mathrm{OOH}$, держава, водні ресурси якої не перевищують 1,7 тис. м³ стоку на рік на одну людину, вважається незабезпеченою водою. У Канаді ця величина дорівнює 94,3 тис. $\mathrm{M}^{3}$, у Росії - 31,0 тис. м³, у Швеції - 19,7 тис. м³, у США - 7,4 тис. М $^{3}$, у Білорусі 5,7 тис. м $^{3}$, у Франції - 3,4 тис. $\mathrm{M}^{3}$, в Англії - 2,5 тис. $\mathrm{M}^{3}, \mathrm{y}$ Німеччині - 1,9 тис. $\mathrm{M}^{3}$, у Польщі - 1,6 тис. м³. Серед 152 країн світу Україна за цим показником посідає 111 місце [8].

\section{ГИГИЕНИЧЕСКИЕ ПРОБЛЕМЫ ВОДОСНАБЖЕНИЯ В ТЕРНОПОЛЬСКОЙ ОБЛАСТИ \\ Лотоцкая Е.В., Кондратюк В.А., Паничев В.А. ГВУЗ „Тернопольский государственный медицинский университет \\ им. И.Я. Горбачевского Минздрава Украины", ГУ «Тернопольский областной лабораторный центр Минздрава Украины», г. Тернополь}

Целью работы было провести гигиеническую оценку состояния хозяйственно-питьевого водоснабжения в Тернопольской области и анализ динамики качества питьевой воды из источников централизованного и децентрализованного водоснабжения за 2013-2016 годы.

Объект и методы исследования. Анализ состояния и качества питьевой воды централизованных и децентрализованных источников водоснабжения Тернопольской области выполнен по материалам исследований, проведенных в 20132016 годах в рамках государственного мониторинга качества природных и питьевых вод. Результаты. По водообеспеченности

Тернопольская область занимает 15 место в Украине. Распределение водных ресурсов по территории области неравномерно. Проблема качества питьевой воды была и остается в области крайне актуальной, чрезвычайно острой и является серьезной угрозой для здоровья населения. Качество питьевой воды из системы централизованного водоснабжения ухудшается из-за отсутствия санитарно-защитных зон, неудовлетворительного технического состояния водоочистных сооружений и водопроводных сетей, недостаточного контроля и неэффективности технологий водоподготовки, низкого уровня обеспеченности водой на душу населения. Качество питьевой воды в источниках децентрализованного водоснабжения Тернопольской области по химическим и бактериологическим показателям в последние годы остается неудовлетворительной и имеет неустойчивый характер.

Для улучшения качества питьевой воды в источниках децентрализованного водоснабжения области предлагается усилить мониторинг источников качества водоснабжения региона, создать информационный центр по обработке и обобщению данных качества воды, повысить эффективность управления водным хозяйством, охраной и защитой водоемов от вредного антропогенного воздействия.

Ключевые слова: качество воды, централизованное водоснабжение, децентрализованное водоснабжение. 
Для Тернопільської області питання якості та безпечності питної води $€$ надзвичайно актуальним, адже це один із регіонів зі значним антропогенним навантаженням на водні джерела та нестачею достатньої кількості прісної води. За даними державної статистичної звітності, Тернопільська область посідає перше місце серед областей 3 найбільшим відсотком досліджених проб питної води, що не відповідають санітарним нормам за санітарно-бактеріологічними показниками [9].

Метою роботи було провести гігієнічну оцінку стану господарсько-питного водопостачання у Тернопільській області та аналіз динаміки якості питної води за 2013-2016 роки із джерел централізованого та децентралізованого водопостачання.

Об'єкт та методи дослідження. Аналіз стану та якості питної води із централізованих та децентралізованих джерел водопостачання Тернопільської області виконано за матеріалами досліджень, проведених останніми роками (2013-2016) у рамках державного моніторингу якості природних та питних вод [9-11].

\section{Структура водоспоживання у Тернопільській області 2016 році (за даними Тернопільського обласного \\ Рисунок 1} управління водних ресурсів http://www.vodgosp.te.ua)

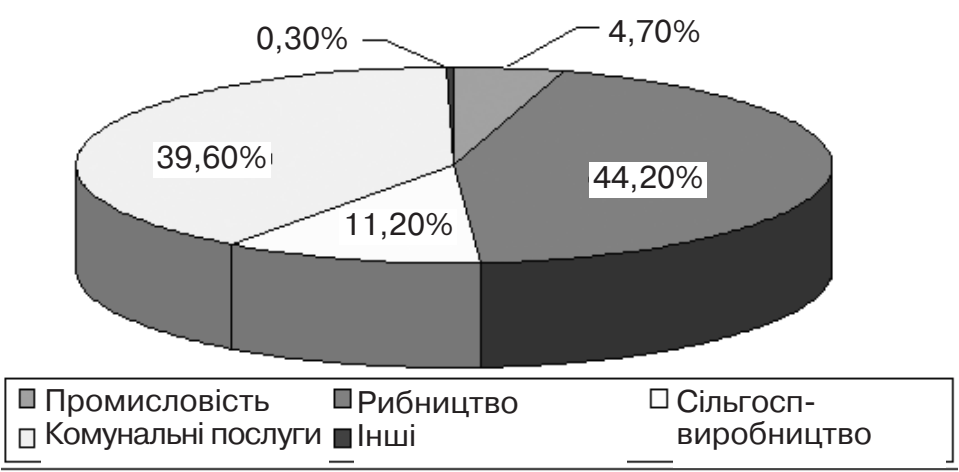

Динаміка використання води (млн, області за 1990-2015 роки

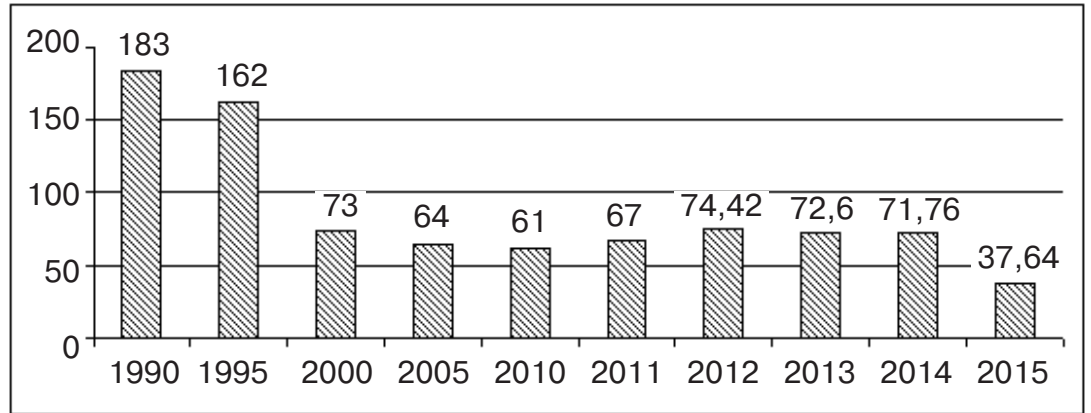

Рисунок 2

Результати та їх обговорення. За водозабезпеченістю

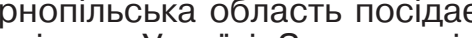
5 місце в Україні. Залежно від канця року на одного меш1-1,5 тис. м $^{3}$ води на рік. До того ж розподіл водних ресурсів територією області нерівнопеченими є Борщівський, Гусятинський, Заліщицький та Чортківський райони, які розрічки Дністер.

Водні ресурси області у значній кількості використовуються для риборозведення, комусоло-побутових потреб, проського водопостачання, потреб енергетики, рекреаційних тощо (рис. 1). меншення обсягів використання води - на 6\%. Якщо у вували 183 млн. м³ , то у $2000-$ вже 73 млн. м³. Це зумовлене спим скороченням водота ще більш значним зменшенням подачі води на зрошення. Використання води 2015 року в області знову значно зменшилося: $з$ 71,76 млн. м³ до 37,64

\section{жä} ський обласний лабораторний центр МОЗ України» у 2016 році перебувало 456 джерел централізованого водопостачання населення, 3 них 40 комунальних, 128 відомчих, 288 сільських водогонів. Загальна кількість джерел централізованого водопостачання за останні 7 роки зменшилася на 15 одиниць, або на $3 \%$. При цьому кількість відомчих водогонів зменшилася майже на 19\% (30 одиниць). Але при цьому в області зросла кількість сільських джерел централізованого водопостачання на 5,5\% та комунальних водогонів - на $27 \%$.

При цьому необхідно враховувати, що технічна база системи централізованого питного водопостачання застаріла. Якщо по Україні у середньому понад чверть обладнання насосних станцій централізованих систем питного водопостачання потребують замі- 
HYGIENIC PROBLEMS OF WATER SUPPLY IN TERNOPIL REGION

Lototska O.V., Kondratiuk V.A., Panichev V.O. SHEI "Ternopil State I.Ya. Horbachevskyi Medical University, Ministry of Public Health of Ukraine" SI "Ternopil Oblast Laboratory Center, Ministry of Public Health of Ukraine"

Objective. We carried out a hygienic assessment of the state of domestic-and-drinking water supply in Ternopil region and analyzed a dynamics of drinking water quality from the sources of centralized and decentralized water supply over 2013-2016.

Materials and methods. The analysis of state and quality of drinking water of centralized and decentralized water supply sources in Ternopil region was performed on the basis of the investigations conducted over the past years (2013-2016) within the framework of national monitoring of the quality of natural and drinking water.

Results. In water supply, Ternopil region takes 15-th place in Ukraine. Distribution of water resources across the territory of the region is uneven. The problem of drinking water quality was and remains extremely urgent in the region and is a serious threat to the health of the population. The quality of drinking water from the centralized water supply system is deteriorating due to the lack of sanitary protection zones, the unsatisfactory technical condition of water treatment plants and water supply networks, insufficient control and inefficiency of water treatment technologies, and low level of water provision per capita. The quality of drinking water in the sources of decentralized water supply in Ternopil region in terms of chemical and bacteriological indicators in recent years remains unsatisfactory and unstable.

In order to improve the quality of drinking water in the sources of decentralized water supply in Ternopil region, it is proposed to strengthen monitoring of sources of water quality in the region, to create information centers for the processing and generalization of water quality data, and to increase the efficiency of water management, protection, and protection of water bodies from harmful anthropogenic influences.

Keywords: water quality, centralized water supply, decentralized water supply. ни, то у Тернопільській області цей показник становить 65\%. Процес заміни обладнання відбувається надто повільно. Так, наприклад 2012 року замінено було лише 5\% від потреби. Тривала експлуатація водопровідних мереж і обладнання без ремонту, їхня фізична зношеність та часті

прориви негативно впливають на якість питної води у містах і селищах області, що сприяє бактеріологічній забрудненості води безпосередньо у розподільчих мережах.

На жаль, Тернопільська область належить до областей 3 найбільшою питомою вагою водогонів господарсько-пит-

Рисунок 3

Питома вага водогонів господарсько-питного водопостачання у Тернопільській області, що не відповідають санітарним нормам

(за даними державної статистичної звітності)

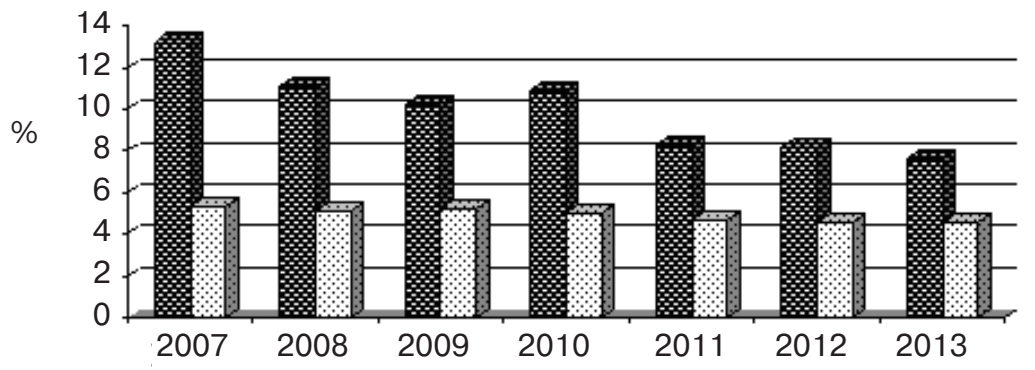

Роки спостереження

Середній показник по Україні 웅'Тернопільська обл.

Таблиця 1

Якість води у централізованих джерелах водопостачання у 2013-2016 роках

\begin{tabular}{|c|c|c|c|c|c|c|c|}
\hline \multirow{3}{*}{ Рік } & \multirow{3}{*}{$\begin{array}{c}\text { Кількість } \\
\text { джерел } \\
\text { водопо- } \\
\text { стачання }\end{array}$} & \multicolumn{6}{|c|}{ Досліджено проб } \\
\hline & & \multicolumn{3}{|c|}{ мікробіологічні показники } & \multicolumn{3}{|c|}{ санітарно-хім. показники } \\
\hline & & Разом & $\begin{array}{c}3 \text { них не від- } \\
\text { повідають }\end{array}$ & $\%$ & Разом & $\begin{array}{c}3 \text { них не від- } \\
\text { повідають }\end{array}$ & $\%$ \\
\hline 2013 & 459 & 2448 & 161 & 6,57 & 2961 & 293 & 9,89 \\
\hline 2014 & 457 & 3045 & 282 & 9,25 & 3678 & 293 & 7,96 \\
\hline 2015 & 456 & 3047 & 368 & 12,07 & 3806 & 433 & 11,37 \\
\hline 2016 & 456 & 3246 & 461 & 14,2 & 2714 & 254 & 9,4 \\
\hline
\end{tabular}

ного водопостачання, що не відповідають санітарним нормам (рис. 3). Так, 10,9\% з них не відповідають санітарним нормам порівняно з середнім показником по Україні - близько 3,9\%. Водогонів комунальних систем, що не відповідають санітарним нормам - 8,6\%, сільських - 6,3\%, відомчих 2,3\%. Із загальної кількості водогонів не відповідають санітарним нормам через відсутність зон санітарної охорони 63,2\%. Але якщо в Україні кількість таких водогонів за останні роки поступово зменшується (з 13,2\% у 2007 р. до 7,6\% у 2013 р., тобто в 1,7 рази), то на Тернопільщині це малопомітно - 3 5,2\% до 4,6\% (рис. 3) через те, що більшість водопровідних мереж експлуатується понад 40-50 років без заміни і капітального ремонту.

Технічний стан системи централізованого питного водопостачання у Тернопільській області застарілий: 40-50\% його потребують невідкладних реноваційних робіт. Це призводить до частих пошкоджень у системі водопостачання, які негативно впливають на якість питної води і сприяють бактеріологічному забрудненню безпосередньо у розподільчих мережах.

За даними державної статистичної звітності, Тернопільська область має найбільший відсоток негативних проб питної води, які не відповідають санітарним нормам за санітарно-бактеріологічними показниками. У 2013 році їх 
було $6,57 \%$, у 2014 р. - 9,25\%, у 2015 р. - 12,07\%. 2016 року 3 досліджених 3246 зразків питної води за мікробіологічними показниками 461 (14,2\%) не відповідали санітарно-гігієнічним вимогам (табл. 1). 3 таблиці 1 бачимо, що за санітарно-хімічними показниками кількість негативних результатів забруднень порівняно з попереднім роком зменшилася.

Останнім часом якість води із джерел централізованого водопостачання у містах Чортків, Борщів, Теребовля та окремих сільських водогонів Кременецького, Борщівського, Теребовлянського та Козівського районів дещо погіршилася. Причин цього може бути декілька: забруднення водоносних горизонтів через сільськогосподарську діяльність, значну кількість проривів на мережах внаслідок зношеності, відсутність санітарно-захисних зон тощо.

Під моніторингом спеціалістів Державної установи «Тернопільський обласний лабораторний центр МО3 України» у 2016 р. перебувало 4056 джерел децентралізованого водопостачання, з них 3708 колодязів, 158 каптажів та 195 артезіанських свердловин. За останні роки їх стало менше вдвічі (колодязів - на 46\%, каптажів на $44 \%$, артезіанських свердловин - на 52\%).

За даними державної статистичної звітності, у Тернопільській області за останні роки (табл. 2) високий відсоток зразків води із децентралізованих джерел водопостачання не відповідає санітарно-бактеріологічними вимогами (2013 р. 9,4\%, 2014 p. - 14,79\%, 2015 р. - 16,06\%). У 2016 році з досліджених 4007 зразків не відповідали нормам 793 (19,8\%).

Надалі залишаються вищими за середні обласні бактеріоло- гічні показники у Борщівському, Заліщицькому, Збаразькому, Кременецькому, Підволочиському, Чортківському та Тернопільському районах.

\section{Висновки}

1. Проблема якості питної води була й залишається в області вкрай актуальною, надзвичайно гострою і є серйозною загрозою для здоров'я населення.

2. У результаті проведеного аналізу було встановлено, що якість питної води із системи централізованого водопостачання погіршується через відсутність санітарно-захисних зон, незадовільний технічний стан водоочисних споруд і водопровідних мереж, недостатній контроль і неефективність технологій водопідготовки, низький рівень забезпеченості водою на душу населення.

3. На основі проведених досліджень виявлено, що ситуація 3 якісним станом питної води у джерелах децентралізованого водопостачання Тернопільської області за хімічними та бактеріологічними показниками протягом останніх років залишається незадовільною й має нестійкий характер.

4. Для покращання якості питної води у джерелах децентралізованого водопостачання Тернопільської області пропонується посилити моніторинг джерел якості водопостачання регіону, створити інформаційний центр 3 обробки та узагальнення даних якості води і підвищити ефективність управління водним господарством, охороною і захистом водойм від шкідливого антропогенного впливу.

ЛІТЕРАТУРА

1. Прокопов В.О.

Липовецька О.Б. Оцінка якості питної води з підземних водо-

Таблиця 2

Якість води у децентралізованих джерелах водопостачання за 2013-2016 роки

\begin{tabular}{|c|c|c|c|c|c|c|c|}
\hline \multirow{3}{*}{ Рік } & \multirow{3}{*}{\begin{tabular}{|c|} 
Кількість \\
джерел \\
водопо- \\
стачання
\end{tabular}} & \multicolumn{6}{|c|}{ Досліджено проб } \\
\hline & & \multicolumn{3}{|c|}{ мікробіологічні показники } & \multicolumn{3}{|c|}{ санітарно-хім. показники } \\
\hline & & Разом & $\begin{array}{c}3 \text { них не від- } \\
\text { повідають }\end{array}$ & $\%$ & Разом & $\begin{array}{c}3 \text { них не від- } \\
\text { повідають }\end{array}$ & $\%$ \\
\hline 2013 & 3128 & 1787 & 168 & 9,4 & 1788 & 364 & 20,35 \\
\hline 2014 & 3499 & 7112 & 1052 & 14,79 & 4144 & 413 & 9,96 \\
\hline 2015 & 4061 & 7804 & 1254 & 16,06 & 3376 & 548 & 16,23 \\
\hline 2016 & 4056 & 4007 & 793 & 19,8 & 6914 & 1338 & 19,4 \\
\hline
\end{tabular}

джерел України з погляду впливу на стан здоров'я населення. Науковий вісник НМУ. 2012. Вип. 4. С. 122-126.

2. Прокопов В.О. Стан та якість питної води централізованих систем водопостачання України у сучасних умовах (погляд на проблему з позицій гігієни). Гігієна населених місць : зб. наук. пр. К., 2014.

Вип. 64.

C. $56-67$.

\section{3. Аналіз актуальних} чинників погіршення якості питного водопостачання у контексті національної безпеки України. Аналітична записка. Режим доступу:

http://www. niss.gov.ua/articles/1037

4. Григоренко Л.В. Вплив якості питної води на стан здоров'я сільського населення. Гігієна населених місць : зб. наук. пр. К., 2014. Вип. 64 C. 80-86.

5. Мосейчук А.А., Бойко І.А Оцінка якості питної води у джерелах децентралізованого водопостачання Полтавської області. Вісник

Полтавської державної аграрної академії . 2011. № 4. C. $12-17$.

6. Семчук Г.М. Народу України - якісну питну воду. Водопостачання та водовідведення. 2008. Спецвипуск.

C. $2-5$

7. Пономаренко Н.П.,

Коршун М.М. Оцінка якості господарсько-питного водопостачання районів Чернігівської області. Актуальні проблеми сучасної медицини. 2014. Т. 14, Вип. 2. С. 37-43.

8. Стасюк С., Майданович В. Проблема питної води в Україні. Режим доступу : https://aw-therm.com.ua/problema-pitnoyi-vodi-v-ukrayin

9. Національна доповідь про якість питної води та стан питного водопостачання в Україні 
visnyk Natsionalnoho med. universytetu. $2012 ; 4$ : 122-126 (in Ukrainian).

2. Prokopov V.O. Stan ta yakist pytnoi vody tsentralizovanykh system vodopostachannia Ukrainy v suchasnykh umovakh (pohliad na problemu z pozytsii hihiieny) [State and Quality of Drinking Water from Centralized System of Water Supply of Ukraine under Modern Conditions (Standpoint on the Problem from the Point of View of Hygiene)]. In : Hihiiena naselenykh mists [Hygiene of Settlements]. Kyiv ; 2014 ; 64 : 56-67 (in Ukrainian).

3. Analiz aktualnykh chynnykiv pohirshennia yakosti pytnoho vodopostachannia $v$ konteksti natsionalnoi bezpeky Ukrainy. Analitychna zapyska

[Analysis of the Actual Factors of Drinking Water Quality Deterioration in the Context of National Safety of Ukraine. Analytical Note]. URL : http://www. niss.gov.ua/articles/1037 (in Ukrainian).

4. Hryhorenko L.V. Vplyv yakosti pytnoi vody na stan zdorovia silskoho naselennia [Impact of Drinking Water Quality on the Health of State of Rural Population]. In : Hihiiena naselenykh mists [Hygiene of Settlements]. Kyiv ; 2014 ; 64 : 80-86 (in Ukrainian).

5. Moseichuk A.A., Boiko I.A. Otsinka yakosti pytnoi vody v dzherelakh detsentralizovanoho vodopostachannia Poltavskoi oblasti [Assessment of Drinking Water Quality in the Sources of Decentralized Water Supply of Poltava Oblast]. Visnyk Poltavskoi derzhavnoi ahrarnoi akademii. 2011; 4 : 12-17 (in Ukrainian).

6. Semchuk H.M.

Vodopostachannia ta vodovidvedennia. 2008 ; Special Issue : 2-5 (in Ukrainian).

7. Ponomarenko N.P., Korshun M.M. Otsinka yakosti hospodarsko-pytnoho vodopostachannia raioniv Chernihivskoi oblasti [Assessment of the Quality of Domestic-and-Drinking Water Supply in the Regions of Chernihiv Oblast]. Aktualni problemy suchasnoi medytsyny. 2014 ; 14 (2) : 37-43 (in Ukrainian)

8. Stasiuk S., Maidanovych V. Problema pytnoi vody v Ukraini [The Problem of Drinking Water in Ukraine]. URL https://awtherm.com.ua/problema-pitnoyi-vodi-v-ukrayin (in Ukrainian)

9. Natsionalna dopovid pro yakist pytnoi vody ta stan pytnoho vodopostachannia v Ukraini u 2009 rotsi / Minregionbud Ukrainy [National Report on Drinking Water Quality and State of Drinking Water Supply in 2009 in Ukraine]. Kyiv ; 2009. 710 p. URL : http://old.minregion. gov.ua/zhkh/pitna-voda-tapitne-vodopostachannyavodovidvedennya-teplopostachannya-502164/novini$500177 /$ ?page $=2$ (in Ukrainian)

10. Natsionalna dopovid pro yakist pytnoi vody ta stan pytnoho vodopostachannia v Ukraini u 2010 rotsi / Minregionbud Ukrainy [National Report on Drinking Water Quality and State of Drinking Water Supply in 2010 in Ukraine/Minregionbud of Ukraine]. Kyiv ; 2010 : 564 p. URL : http://old.minregion. gov.ua/attachments/files/zhkh/ Vodopostachannya/ 2010 pdf (in Ukrainian).

11. Natsionalna dopovid pro yakist pytnoi vody ta stan pytnoho vodopostachannia v Ukraini $u$ 2012 rotsi [National Report on Drinking Water Quality and State of Drinking Water Supply in 2012 in Ukraine]. URL : http://minregion.gov.ua/discussion/proektnacionalnoyi-dopovidi-pro-yakist-pitnoyi-vodi-tastan-pitnogovodopostachannya-v-ukrayini-u2012-roci/

(in Ukrainian).

12. Pro stan zabezpechennia naselennia Ternopilskoi oblasti dobroiakisnoiu pytnoiu vodoiu [On the State of the Provision of the Population in Ternopil Oblast with the High Quality Drinking Water]. URL :

http://www.terses.gov.ua/index. php/shcho-varto-znaty/1085pro-stan-zabezpechennia-naselennia-ternopilskoi-oblastidobroiakisnoiu-pytnoiu-vodoiu (in Ukrainian).

13. Blazhkevych L.I. Voda pytna. Shche raz pro problemy vodopostachannia v Ternopilskii oblasti [Drinking Water. On the Problem of Water Supply in Ternopil Oblast Once Again]. URL : http://www.terses.gov. ua/index.php/shcho-vartoznaty/1635-voda-pytna-shcheraz-pro-problemyvodopostachannia-v-ternopilskii-oblasti (in Ukrainian).

Надійшла до редакції 02.09.2017

1. Prokopov V.O. Lypovetska O.B. Naukovyi 